\title{
GENERACJE RZECZY
}

\section{SOLIDARNOŚĆ MIEDZYPOKOLENIOWA I MIEDZYPOKOLENIOWE AMBIWALENCJE}

Solidarność międzypokoleniowa może zostać zdefiniowana jako forma społecznej spójności zachodzącej pomiędzy jednostkami przynależącymi do różnych generacji (na przykład pomiędzy rodzicem a dzieckiem, pomiędzy dziadkiem a wnukiem) albo pomiędzy różnymi kategoriami wiekowymi (pomiędzy młodymi a dorosłymi; pomiędzy dorosłymi a starszymi) ${ }^{1}$.

Wielu autorów zwraca uwagę na to, że s pójn ość ta ma charakter złożony i można wskazać na kilka przynajmniej jej wymiarów, wśród których najważniejsze to: wymiar emocjonalny (przywiązanie, poczucie bliskości, miłość); wymiar asocjacyjny (interakcje, relacje i związki zachodzące pomiędzy jednostkami); wymiar konsensualny (zgoda opinii i przekonań, podzielanie wartości); wymiar fu n k cj o n a ln y (wzajemna zależność, wymiana dóbr i usług pomiędzy przedstawicielami poszczególnych pokoleń); wymiar normatyw ny (oczekiwania dotyczące międzypokoleniowej pomocy, zobowiązania rodziców wobec dzieci i dzieci wobec rodziców); wymiar s tr u k tu raln y (stwarzanie przez różnorodne struktury warunków i okoliczności sprzyjających interakcjom i związkom pomiędzy przedstawicielami poszczególnych pokoleń) ${ }^{2}$. Wielowymiarowość solidarności międzypokoleniowej polega również na tym, iż -jak wspomniałem wyżej - rozgrywa się ona zarówno pomiędzy poszczególnymi jednostkami, jak i pomiędzy kohortami demograficznymi i historycznymi. Oznacza to z kolei, że tego rodzaju spójność (jej siła i zakres), jest funkcja trajektorii konkretnej relacji biograficznej łączącej dwie osoby oraz stanowiących elementy tożsamości poszczególnych pokoleń definicji, oczekiwań, zobowiązań odnoszących się do innych kategorii pokoleniowych. Zgodnie z takim sposobem myślenia - solidarność łącząca syna i ojca to zarówno produkt historii ich związku, wspólnych doświadczeń i wzajemnego doświadczania siebie, jak i specyficzna relacja, którą kształtują: międzygeneracyjne stereotypy,

\footnotetext{
${ }^{1} \mathrm{Na}$ ten temat zob. R. Katz, A. Lowenstein, J. Phillips, S. O. Daatland, Theorizing Intergenerational Family Relations: Solidarity, Conflict, and Ambivalence in Cross-national Contexts, w: A. Bengtson, K. R. Acock, P. Allen, D. M. Klein (red.), Sourcebook of Family Theory and Research, London 2005, s. 393-407.

${ }^{2} \mathrm{Na}$ temat koncepcji ,wielowymiarowej solidarności międzypokoleniowej” zob. V. L. Bengtson, T. Biblarz, E. Clarke, R. Giarrusso, R. E. L. Roberts, J. Richlin-Klonsky, M. Silverstein, Intergenerational Relationships and Ageing: Families, Cohorts, and Social Change, w: J. M. Claire, R. M. Allman (red.), The Gerontological Prism: Developing Interdisciplinary Bridges, New York 2000, s. 115-148.
} 
wyobrażenia na temat młodych wśród dorosłych i na odwrót, nierówności dostępu do rynku pracy i świadczeń ze strony państwa i tak dalej. Tego rodzaju nakładanie się porządków mikro- i makrostrukturalnych dodatkowo komplikuje fakt, iż w obrębie każdej z kohort demograficznych mamy do czynienia z ogromnym zróżnicowaniem strukturalnym, które relatywizuje relacje rodzinne poszczególnych kategorii stratyfikacyjnych ${ }^{3}$.

Warto też dodać, że dziś, za sprawą wszechobecności ,technologii społecznego nasycania"4, każdy z nas (jako przedstawiciel określonej generacji, kategorii społecznej, klasy, członek rodziny, rówieśnik itd.) świadomy jest tego, jak żyją osoby należące do innych od naszego pokoleń, oraz tego, jaki charakter mają relacje łączące osoby reprezentujące różne grupy wiekowe, stratyfikacyjne, etniczne i rasowe. Solidarność międzygen eracyjna jest więc kształtowana przez oczekiwania i definicje, które maja charakter egzogenny wobec konkretnego związku osób w różnym wieku, jak również wobec relacji łączących pokolenia, do których one należą. Nasze wyobrażenia na temat tego, jak powinny przebiegać relacje pomiędzy starymi a młodymi, są więc przenicowane przez niezliczone medialne reprezentacje tego rodzaju stosunków, z których każda rości sobie pretensje do pełnienia roli mitu wyjaśniającego nam naturę rzeczywistości ${ }^{5}$, i to mimo że są one zazwyczaj ze sobą sprzeczne i wykluczają się wzajemnie jako deskrypcje rzeczywistości czy modele działania w jej obrębie.

Dla dopełnienia tego ogromnie złożonego obrazu czynników kształtujących solidarność międzypokoleniową należy dodać też i to, że - zwłaszcza dziś rozgrywa się ona w zmiennym i niestabilnym kontekście społecznym, ekonomicznym oraz politycznym, który wymusza przedefiniowywanie międzygeneracyjnych stosunków i zobowiązań z nich wynikających. Do najważniejszych z tego rodzaju przeobrażeń w ostatnich dekadach należą niewątpliwie: starzenie się społeczeństw i wynikające stąd konflikty wokół polityki fiskalnej, dystrybucji środków przez państwo, zabezpieczeń emerytalnych, szans na rynku pracy; ,„przeładownie państwa” ${ }^{6}$ i będąca jego skutkiem niemożność realizacji przez jego instytucje funkcji opiekuńczych; przeobrażenia struktury rodziny i relacji rodzinnych; wysoka mobilność jednostek, wielokulturowość i globalizacja życia społecznego; zwiększająca się liczba pracujących kobiet; opóźnienie momentu wchodzenia ludzi młodych w dorosłość oraz wzrost stopy bezrobocia wśród tej kategorii wiekowej; powiększająca się skala ekonomicznego, a co za tym idzie - również społecznego rozwarstwienia; kryzysy na rynkach finansowych i wiele innych nie mniej istotnych kwestii ${ }^{7}$.

Solidarność międzygeneracyjna więc to kategoria opisująca takie rodzaje stosunków, których podstawową cechą jest złożoność, co z kolei oznacza, iż można w bardzo prosty sposób ją modelować, przeobrażać, wzbudzać -

\footnotetext{
${ }^{3} \mathrm{Na}$ ten temat zob. P. Bourdieu, Dystynkcja, Warszawa 2006.

${ }^{4}$ K. J. Gergen, Nasycone Ja. Dylematy tożsamości w życiu wspótczesnym, Warszawa 2009.

${ }^{5}$ D. Czaja (red.), Mitologie popularne. Szkice z antropologii wspótczesności, Warszawa 1994.

${ }^{6}$ M. Hirszowicz, Skad, ale dokad? Spoteczeństwo u progu nowej ery, Warszawa 2007, s. 144-148.

${ }^{7}$ Kompletny opis tego nowego kontekstu dla relacji międzygeneracyjnych oraz społecznych reakcji na nie można znaleźć w raporcie Eurobarometr: Intergenerational Solidarity Analytical Report, 2009 (dokument elektroniczny: http://ec.europa.eu/public_opinion/flash/fl_269_en.pdf).
} 
wystarczy przekształcić pojedyncze elementy tego rodzaju relacji. Należy jednak pamiętać o tym, że nie jest to równoznaczne $\mathrm{z}$ kontrolowaniem tego rodzaju związków, ponieważ takie enklawowe próby ich przeobrażania zawsze skutkują niezamierzonymi rezultatami, których źródłem jest właśnie złożoność związków pomiędzy pokoleniami. To z kolei oznacza, że o ile bardzo łatwo określić jest pożądany przez wszystkich model relacji międzygeneracyjnych (składają się nań harmonijne, oparte na wzajemnym poszanowaniu i poczuciu odpowiedzialności związki, które przenika duch równości szans, emocjonalnego zaangażowania i miłości), o tyle bardzo trudno jest wskazać na brzegowe choćby warunki, których spełnienie wygeneruje taki właśnie kształt stosunków pomiędzy pokoleniami. Być może więc powinniśmy traktować kategorię solidarności międzygeneracyjnej nie jako kategorię opisową, zdającą relację z jakiegoś istniejącego stanu stosunków pomiędzy poszczególnymi pokoleniami, a raczej jako trudny do zrealizowania i dostępny dla nielicznych ideał, który dodatkowo nie przez wszystkich jest akceptowany ${ }^{8}$.

Dlatego też dużo bardziej płodnym poznawczo pojęciem opisującym relacje międzygeneracyjne jest zaproponowana przez Kurta Lüschera i Karla Pillemera ${ }^{9}$ kategoria ,,ambiwalencji międzypokoleniowej” (intergenerational ambivalence). Odnosi się ona do sprzecznych ze sobą oczekiwań, zobowiązań, norm, działań poszczególnych generacji, do ambiwalencji, które choć dzielą, to jednocześnie stanowią istotę stosunków międzypokoleniowych. Mówiąc jeszcze inaczej: relacje pomiędzy dzieckiem a rodzicem, młodymi a starymi, ze względu na włączenie każdego $\mathrm{z}$ podmiotów tego rodzaju stosunków w splątane sieci społeczne, przesiąknięte są ambiwalencjami, których rozwikłanie stanowi podstawowe zadanie tego rodzaju związków. Oznacza to z kolei, iż te ostatnie nie sa oparte ani na solidarności, ani na konflikcie, ale na próbie poradzenia sobie ze sprzecznościami, które niesie za sobą bycie razem w splątanym, zmiennym świecie. Wystarczy tu przypomnieć sprzeczności pomiędzy systemowym przymusem bycia podmiotem a zobowiązaniami rodzinnymi; pomiędzy pracą i karierą zawodową a społecznymi oczekiwaniami co do opieki nad dziećmi i starzejącymi się rodzicami; pomiędzy potrzebą utrzymywania silnych relacji z rodzina prokreacji a podobna potrzebą odczuwana wobec rodziny pochodzenia; pomiędzy więziami łączącymi nas z rodzicami a tymi, które wiążą nas z rówieśnikami, pomiędzy mediami komunikacyjnymi i stylami komunikacji preferowanymi przez rodziców i dziadków a tymi, za pomoca których młodzi porozumiewaja się z rówieśnikami i tak dalej, by nie tylko dostrzec, że międzygeneracyjne relacje przenikają ambiwalencje, ale też że to sposób ich rozstrzygania, a nie odgórnie ustanowione ideały międzypokoleniowych stosunków, kształtują konkretne związki łączące jednostki należące do różnych generacji. Co więcej - specyfika poszczególnych kategorii pokoleniowych jest określona $\mathrm{w}$ dużej mierze poprzez to, jak radza sobie one ze sprzecznościami obecnymi w relacjach ze starszymi generacjami,

\footnotetext{
${ }^{8}$ Wskazują na to wyniki badań cytowanych w powyżej wspominamy raporcie (np. ponad $1 / 3$ mieszkańców Europy twierdzi, że bardzo trudno pogodzić ze sobą opinie, wartości, światopogląd ludzi starszych i młodych, $20 \%$ uważa, że ludzie starsi są obciążeniem dla społeczeństwa).

${ }^{9}$ K. Lüscher, K. Pillemer, Intergenerational Ambivalence. A New Approach to the Study of Parent-Child Relations in Later Life, ,Journal of Marriage and Family” 60, 1998.
} 
ambiwalencjami, charakterystycznymi dla określonego czasu i miejsca ${ }^{10}$. Na marginesie warto dodać, że przyjmując powyższe założenia, jesteśmy też w stanie dostrzec, iż specyfika poszczególnych pokoleń ma charakter wybitnie relacyjny, nie jest też określona przez jedno, inicjujące doświadczenie (jak wojna, zmiana systemowa, dramatyczne wydarzenie społeczne), ale przeobraża się wraz ze zmieniającymi się międzygeneracyjnymi sprzecznościami, które należy rozwiązać.

Układanie relacji międzypokoleniowych, stanowiące integralny element codziennych praktyk oraz polityki społecznej państwa, powinno być więc skoncentrowane nie tyle na tworzeniu warunków do solidarności międzygeneracyjnej, ile raczej na wypracowywaniu sposobów rozwiązywania sprzeczności, z którymi borykają się jednostki należące do różnych kategorii wiekowych ${ }^{11}$. Powinniśmy więc nie tylko prowadzić akcje społeczne przeciwko ageizmowi, lecz także dostrzec, iż jest on często przejawem sprzeczności pomiędzy normą społecznego szacunku wobec osób starszych a koniecznością rywalizacji z nimi na rynku pracy; nie tylko przypominać dorosłym o ich obowiązkach wobec dzieci, lecz również dostrzec, że zaniedbywanie tych ostatnich przez rodziców, to nie tyle wybór, ile raczej dramatyczna konsekwencja sprzeczności pomiędzy wysokimi współczesnymi wymaganiami wobec opieki rodzicielskiej a równie wyśrubowanymi standardami obowiązującymi w kontekście zawodowym; nie tylko przypominać dorosłym obywatelom o obowiązkach prokreacyjnych, których wypełnianie ma w przyszłości wzmocnić wydolność systemu świadczeń społecznych, ale raczej próbować rozwiązywać sprzeczność pomiędzy generowaną rynkowo potrzebą nowych doświadczeń i przeżyć a znacznie ograniczającymi możliwości jej zaspokojenia zobowiązaniami rodzicielskimi.

Kategoria solidarności międzypokoleniowej wydaje się problematyczna nie tylko dlatego, że jest zbyt normatywna, ale również dlatego, że operuje ona na zbyt wysokim poziomie ogólności. Normatywny charakter tego pojęcia przesuwa naszą uwagę na pojęcie ambiwalencji międzypokoleniowych, którego przydatność jest nie tylko funkcją jego opisowego charakteru, ale też tego, że zwraca ono uwagę na to, iż układanie relacji międzygeneracyjnych powinno być podporządkowane próbom rozwiązywania sprzeczności, które niesie za soba bycie ze sobą jednostek należących do różnych kategorii wiekowych, sprzeczności, które pojawiają się zarówno na poziomie mikro- jak i makrospołecznym.

\footnotetext{
${ }^{10}$ Niekiedy sprzeczności te są rozwiązywane poprzez zainicjowanie zmiany systemu postrzeganego jako zbyt faworyzujący tylko jedną $\mathrm{z}$ generacji (tak jak miało to miejsce w wypadku pokolenia kontrkulturowego buntu); kiedy indziej poprzez eksponowanie międzygeneracyjnego konfliktu jako nierozwiązywalnego (tak jak ma to miejsce w wypadku pokolenia subkultur), kiedy indziej poprzez prowadzenie podwójnego życia, opartego na dualnym systemie wartości w zależności od tego, do jakiej generacji należy osoba, z którą wchodzimy w tego rodzaju relacje, albo poprzez ekstremalne osłabienie relacji międzygeneracyjnych czy też wsparcie kultur terapeutycznych (toksyczni rodzice i toksyczne dzieci) itd.

11 Oznacza to również, iż solidarność i sprzeczności nie stanowią opozycji - rozwiązywanie sprzeczności nie zawsze prowadzi do powiększenia zakresu spoistości, może skutkować również konfliktem.
} 


\section{SPRZECZNOŚCI MIĘDZYPOKOLENIOWE I KULTURA MATERIALNA}

Jeżeli uznamy, że istotą międzygeneracyjnych relacji nie jest ani solidarność, ani konflikt, ale wielowymiarowe sprzeczności, które tego rodzaju stosunki przenikaja, to powinniśmy też dostrzec, iż ambiwalencje te, choć przejawiaja się na poziomie normatywnym, świadomościowym, moralnym (albo - generalniej - w wyborach, których dokonuja jednostki), to maja swoje źródło w sprzecznościach przenikających kontekst działania jednostek należących do różnych kategorii wiekowych. Jednym z najważniejszych aspektów tego kontekstu sa zaś przedmioty i dobra materialne. Trudno bowiem sobie wyobrazić jakiekolwiek działanie, w którym nie pośredniczyłyby one jako jego miejsce, obiekt, narzędzie, cel, medium, i to one właśnie, jako istotne elementy relacji międzypokoleniowych, zarówno generują, jak i obiektywizują międzygeneracyjne sprzeczności.

Procesy modernizacyjne i prymat rynku w roli głównego źródła dóbr materialnych oznaczają ogromną akcelerację zmian panoplii przedmiotów ${ }^{12}$ stanowiących kontekst naszego codziennego życia. Przekształcenia te nie polegają dziś tylko na stopniowej wymianie pojedynczych obiektów, ale na pojawianiu się całych nowych generacji rzeczy. Dzieje się tak nie tylko za sprawą systematycznego kreowania „koni pociągowych” takich przeobrażeń, jak nowe źródła energii, tworzywa sztuczne, technologie komunikacyjne i komputerowe, ale też na mocy „efektu Diderota" ${ }^{13}$ rządzącego zachowaniami konsumenckimi lub korporacyjnych strategii sezonowego wprowadzania nowych produktów na rynek. Efektem obecności tego mechanizmu kształtujacego kulturę materialną rozwiniętych, nowoczesnych społeczeństw jest nie tylko to, że każda z generacji adaptuje się do rzeczywistości za pomoca odmiennego systemu przedmiotów i jest konfrontowana $\mathrm{z}$ nowymi wymaganiami, które niosą za sobą technologiczne innowacje, ale też liczne sprzeczności, które niesie za sobą opisywany tu mechanizm.

Po pierwsze, problematyzuje on uspołeczniające funkcje rodziny (a także szkoły i innych hierarchicznych organizacji opartych na autorytecie i władzy dorosłego oraz podległości tego, który wchodzi dopiero w życie rodzinne) jako instytucji wprowadzającej jednostkę do ludzkiego świata obiektywnego, ponieważ to nie rodzice, a dzieci sa generacją najlepiej przystosowana do życia w świecie, który nie został jeszcze wypróbowany i oswojony przez dorosłych, ale dopiero się staje wraz z dojrzewaniem wchodzącego na scenę społeczną pokolenia. Ta specyficzna prekonfiguratywność ${ }^{14}$, której źródłem są zmiany materialnych aspektów rzeczywistości, rodzi więc sprzeczność $\mathrm{w}$ rolach dorosłego pokolenia $-\mathrm{z}$ jednej strony odpowiedzialnego za wytworzenie

\footnotetext{
${ }^{12}$ Używam tu pojęcia wprowadzonego do opisu systemów przedmiotów przez Jeana Baudrillarda w książce System of Objects (J. Baudrillard, The System of Objects, London 1996).

${ }^{13} \mathrm{Na}$ ten temat zob. G. McCracken, Culture and Consumption: New Approaches to the Symbolic Character of Consumer Goods and Activities, Bloomington 1990.

${ }^{14}$ M. Mead, Kultura i tożsamość. Studium dystansu międzypokoleniowego, Warszawa 1978.
} 
adaptacyjnych kompetencji dzieci, a z drugiej, zmuszonego do przebudowywania tych, w które samo jest ono wyposażone, a które okazują się nieprzydatne w nowym i stale ewoluującym kontekście. Sprzeczność, którą można określić jako konieczność jednoczesnego bycia nauczycielem i uczniem, autorytetem i zerusem, podważa i problematyzuje tradycyjnie rozumiane systemy autorytetów, które dzięki wiedzy, doświadczeniu życiowemu i poświadczając własna biografią doniosłość propagowanych wartości, występują w roli żywych ideałów ${ }^{15}$, wyroczni i drogowskazów dla tych, którzy rozpoczynają dopiero swoje dorosłe życie. Nowe przedmioty i technologie stanowiące materialny kontekst życia ujawniają pęknięcie pomiędzy tym hierarchicznym, niezmiennym systemem punktów orientacyjnych a rzeczywistością, której cechą jest niestabilność i zmiana, a tym samym podważają autorytatywność dorosłych jako przewodników po współczesnych światach społecznych.

Po drugie, opisywany tu mechanizm zmieniających się generacji przedmiotów sprawia, że społeczeństwa faworyzują to, co w innym miejscu nazwałem „,prymatem ekstremalnych punktów temporalności obiektów materialnych” a więc to, co jest nowością i to, co zasługuje na miano staroci. Fetyszyzowanie przedmiotów dopiero wprowadzanych na rynek jako lepszych, doskonalszych, ale też pozwalających na demonstrowanie faktu trzymania ręki na pulsie $\mathrm{z}$ jednej strony, oraz traktowanie tego, co pokrywa patyna i co jest stosunkowo rzadkie jako wartości poświadczającej społeczną genealogię jednostki i jej nobliwość z drugiej, rodzi międzygeneracyjne sprzeczności. Ich najpełniejszym wyrazem jest istnienie firm zajmujących się likwidacją zawartości mieszkań pozostawionych dzieciom przez rodziców lub dziadków. Zawartość ta, choć składa się z (potencjalnych) pamiątek, dzięki którym obiektywizacji i utrwaleniu może ulec więź z tymi, którzy odeszli, z perspektywy spadkobierców widziana jest najczęściej jako bezwartościowa, ponieważ ulokowana jest pomiędzy wyżej wskazanymi punktami ekstremalnymi: nowościami i starociami. Oznacza to, że współczesne rotowanie systemu przedmiotów wywołuje sprzeczności $\mathrm{w}$ naszych relacjach z bliskimi: z jednej strony, jesteśmy zobowiązani do pamiętania o nich (a nie ma lepszej formy zobiektywizowania tej obligacji, niż „zamrożenie" ${ }^{17}$ jej w przedmiocie, który ewokuje wspomnienia), ale z drugiej - do „bycia na czasie”, a to wymaga od nas szybkiego zapominania o tym, co było. Czasami sprzeczność ta wyraża się w bardziej prozaicznej formie - jednostka, chcąc adaptować się do zmiennej i cyrkulującej kultury materialnej fetyszyzującej to, co nowe, musi uczynić swój dom i samą siebie „elastyczną"18, a więc gotową na przyjmowanie kolejnych nowości. Te ostatnie wymagaja bowiem miejsca, co $\mathrm{z}$ kolei wymusza równie systematycznie

\footnotetext{
${ }^{15}$ S. Czarnowski, Kult bohaterów i jego społeczne podtoże. Święty Patryk bohater narodowy Irlandii, w: idem, Dzieta, t. 4, Warszawa 1956.

${ }^{16}$ M. Krajewski, Style życia przedmiotów. Zarys koncepcji (w druku).

17 D. Slater, Consumer Culture and Modernity, Cambridge 1997.

${ }^{18}$ Ten przymus traktuję jako jedno z zadań, przed którymi stoimy jako osoby praktykujące ,,reżimy podtrzymujące”, pozwalające odtwarzać się i trwać wspólnocie, jaką tworzą osoby i rzeczy składające się na gospodarstwo domowe. Na ten temat zob. M. Krajewski, Dzisiaj jak wczoraj, jutro jak dziś. Codzienność, przedmioty i reżimy podtrzymujace, w: M. Bogunia-Borowska (red.), Barwy codzienności. Analiza socjologiczna, Warszawa 2009.
} 
realizowane rytuały anihilacji tego, co się zestarzało, a co jeszcze nie może zostać uznane za wartościową staroć. Sprzeczność pomiędzy obowiązkiem pamiętania i przymusem zapominania materializuje się więc $\mathrm{w}$ niemożności pomieszczenia $\mathrm{w}$ naszych domach przedmiotów reprezentujących wszystkie kategorie rzeczy, w niemożności, która skutkuje nieustannie ponawianym porządkowaniem przestrzeni prywatnych i oczyszczaniem ich z obiektów, które nie pozwalają nam trzymać ręki na pulsie. Opisana tu sprzeczność wydaje się problemem technicznym (jak pomieścić w domu dorobek życia, odziedziczone przedmioty i nowe obiekty), ale w istocie posiada ona istotny wymiar moralny, gdyż stawia nas przed dylematem, co jest dla nas ważniejsze: pamięć czy wymagajacca amnezji celebracja tego, co teraz.

Po trzecie, przyspieszenie procesu rotowania przedmiotów rodzi też inny rodzaj sprzeczności, a mianowicie, pęknięcia pomiędzy koniecznością konstruowania wspólnego świata, niezbędnego dla międzypokoleniowej koegzystencji, a oddzielnością społecznych światów poszczególnych generacji, będąca produktem osobnych kultur materialnych, w których przebiega ich życie. Ogromne nakłady finansowe na przezwyciężenie cyfrowego wykluczenia ludzi starszych są najlepszym przykładem tego pęknięcia, bezskuteczność tego działania zaś zostaje zobiektywizowana w setkach sieciowych virali tworzonych przez młodych, a prezentujących starszych ludzi zmagających się z komputerowymi technologiami i przegrywających $\mathrm{z}$ nimi w spektakularny sposób. Rotujące systemy przedmiotów sprawiają więc, iż każda z generacji ma swój własny system obiektów - zazwyczaj jest to panoplia rzeczy, w obrębie której zachodził proces uspołeczniania członków tej konkretnej generacji. Własny, a więc taki, w którym działa ona $\mathrm{w}$ sposób bezproblemowy i naturalny oraz którego specyfika zazębia się $\mathrm{z}$ habitusem będącym jego produktem. Oczywistość swoistego dla określonej generacji świata materialnego objawia się zarówno w nawykowym charakterze relacji z przedmiotami, które się nań składają, jak i w poczuciu obcości oraz bezradności wobec rzeczy pochodzących z materialnych uniwersów odmiennych pokoleń. Pokolenie, dla którego jedyną dostępną technologią ogrzewania domu było palenie $\mathrm{w}$ piecu, $\mathrm{z}$ trudnością będzie akceptować systemy centralnego ogrzewania, i to mimo że te ostatnie sa wygodniejsze w użyciu i tańsze. Dziać się tak będzie dlatego, że te ostatnie wyłączają cały szereg czynności i rytuałów, relacji społecznych towarzyszących tej prostej czynności, jaka jest rozpalenie i podtrzymywanie ognia ${ }^{19}$, a także dlatego, że unicestwiają część praktyk stanowiących integralną część świata osoby wychowanej w czasie, gdy domowe piece były jedynym źródłem ciepła. Na podobnej zasadzie - dla osoby, która zawsze prała swoje ubrania w pralce automatycznej, zupełnie niezrozumiały będzie trud wkładany przez osoby starsze w skomplikowane zabiegi wygotowywania, ręcznego prania, maglowania; z pewnością uzna ona te czynności za zbyt czasochłonne i złożone, a więc też problematyczne jako właściwe techniki utrzymywania garderoby w czystości. Przykłady te wskazuja, iż nasze relacje z przedmiotami nie są nigdy tylko i wyłącznie stosunkami o charakterze czysto technicznym, ponieważ zawsze sa one wmontowane w codzienne praktyki, uruchamiają i podtrzymuja

${ }^{19}$ W. Burszta, Swiat jako więzienie kultury. Pomyślenia, Warszawa 2008. 
nawyki oraz kształcą osobne techniki posługiwania się ciałem ${ }^{20}$. To z kolei sprawia, że osobność materialnych światów, w których żyją poszczególne generacje i które uznaja one za oczywiste i normalne, znajduje swoje odzwierciedlenie w osobności habitusów i tożsamości przedstawicieli poszczególnych pokoleń, a więc rodzi też wspólnotę doświadczeń i sprawia, iż odrębność światów społecznych trudna jest do przezwyciężenia poprzez proste wydyskutowanie punktów spornych i próbę ich eliminacji. Odrębność ta ma bowiem również postać ucieleśnionych nawyków, bezrefleksyjnie podejmowanych działań osadzonych w habitusach wytworzonych poprzez interagowanie ze specyficzną panoplią rzeczy. Sprzeczność, o której tu mowa, jest szczególnie trudna do przezwyciężenia, ponieważ odrębność światów młodych i starych nie przejawia się $\mathrm{w}$ różnicach opinii, poglądów, preferowanych wartości, ale $\mathrm{w}$ osobnych modusach działania, zakorzenionych w odrębnych relacjach ze światem. Próba budowania wspólnego świata nastolatka żyjącego $\mathrm{w}$ świecie przenicowanym i podtrzymywanym $\mathrm{w}$ swoim istnieniu poprzez technologie mobilne $^{21}$, i starszych osób, dla których to telewizja była rewolucyjnym wynalazkiem, jest o tyle trudne do wyobrażenia, że odrębności tych światów nie da się zredukować, pomiędzy mass mediami a mediami sieciowymi, a tym samym zlikwidować, wmontowując te pierwsze w te drugie. Próba ta jest o tyle bezskuteczna, że technologie te pociągaja za sobą osobne praktyki, przyzwyczajenia, wyobrażenia o tym, co normalne i możliwe, osobne codzienne rytuały i tożsamości, które są wokół nich oplecione.

Po czwarte, wymuszane rynkowo rotowanie generacji obiektów materialnych niesie też za sobą inny rodzaj sprzeczności, który z kolei utrudnia solidarność międzypokoleniowa, zwłaszcza w jej asocjacyjnym i strukturalnym wymiarze. Osobność światów materialnych, w których żyja poszczególne generacje, sprawia bowiem, iż przedmioty stają się raczej obiektem sporów i konfliktów, niż sklejają interakcje. Rotowanie systemów przedmiotów powoduje, że w określonym czasie dominuje ich ściśle określona panoplia, co z kolei oznacza, iż każde pokolenie, które ma już swoich następców (i wstępująca wraz z nimi specyficzną kulturę materialną), ma też w swoim doświadczeniu poczucie niedopasowania do rzeczywistości, której źródłem są rzeczy. Poczucie to wzmacnia solidarność wewnątrzgeneracyjna, dlatego że jest ono charakterystyczne dla przedstawicieli konkretnych kohort demograficznych i dlatego że chociaż doświadczenie nieodpowiedniości i niedopasowania dotyka wszystkich pokoleń poza tym, którego kultura materialna aktualnie dominuje, to jednocześnie $\mathrm{w}$ każdej z grup wiekowych przyjmuje ono nieco inną postać, ponieważ odmienne sa jego źródła. Oznacza to z kolei, iż rotujące generacje przedmiotów czynią większość z nas niedostosowanymi do materialnego kontekstu naszego życia, ale też niedostosowanymi w nieco odmienny sposób, zrozumiały tylko dla osób z naszego pokolenia. To z kolei przekreśla możliwość zaistnienia solidarności międzypokoleniowej, gdyż tego rodzaju „pokoleniowa osobność" nie sprzyja interakcjom, nie tworzy też materialnych podstaw ich

\footnotetext{
${ }^{20}$ M. Mauss, Socjologia $i$ antropologia, Warszawa 2001.

${ }^{21} \mathrm{Na}$ ten temat zob. Mtodzi i media. Nowe media a uczestnictwo w kulturze, Raport Centrum Badań nad Kulturą Popularną SWPS (dokument elektroniczny: http://www.mim.swps.pl).
} 
zaistnienia - używamy tych samych rzeczy, ale w inny, określony przez generacyjną przynależność sposób. Sytuacja ta ma szczególnie paradoksalny charakter w odniesieniu do mediów komunikacyjnych, które ulegając procesom gwałtownej mediamorfozy ${ }^{22}$, zamiast łączyć - dzielą, i to na bardzo podstawowym poziomie: prób określenia przez różne generacje, czym media te są, do czego mogą być przydatne, w jaki sposób można ich używać. Sytuacji tej nie zmienia wmontowywanie w hipernowoczesne urządzenia - jak smartfony aplikacji pozwalających na realizację działań powszechnych wśród przedstawicieli starszych pokoleń (np. układanie pasjansa, przygotowanie do spowiedzi, prowadzenie terminarza spotkań), ani dostosowywanie współczesnych interfejsów do potrzeb ludzi starszych (powiększone ekrany i klawiatury telefonów, skrajnie uproszczone oprogramowanie, ograniczenie funkcji i możliwości urządzeń itd.), udoskonalenia te bowiem czynią jeszcze bardziej widzialna niemożność zgrania ze sobą światów społecznych różnych pokoleń.

Po piąte, omawiane tu zjawisko prowokowanej rynkowo, przyspieszonej wymiany kultury materialnej ma też inny skutek - problematyzujący z kolei normatywny wymiar solidarności międzypokoleniowej. Poszczególne systemy przedmiotów wyposażone są bowiem w osobne, często nie wprost wyartykułowane, zasady moralne, które określają sposoby wartościowania obiektów i działań wobec nich podejmowanych, a poprzez to również relacji społecznych, w których rzeczy te pośredniczą. Cechą charakterystyczną współcześnie dominującego systemu przedmiotów jest to, że faworyzuje on to, co nowe, przed tym, co stare; to, co teraz, przed tym, co przedtem i potem; indywiduum przed kolektywem; trwonienie przed oszczędzaniem; tymczasowość przed trwałością; zmianę przed stabilnością i tak dalej. Oznacza to z kolei, iż system ten wyklucza solidarność międzypokoleniową, ponieważ wbrew swojej różnorodności rości sobie pretensje do bycia jedynym, stygmatyzując inne, wcześniejsze od niego systemy przedmiotów jako przestarzałe, niemodne, zbyt mało wydajne, niekompatybilne. Tym samym deprecjonuje on też praktyki związane $\mathrm{z}$ obiektami składającymi się na te wcześniejsze panoplie rzeczy - a więc oszczędzanie, troskę, dbanie, naprawianie, przekazywanie rzeczy przyszłym pokoleniom, gromadzenie ich na poczet wiana i posagu, przekazywanie ich $\mathrm{w}$ spadku. W rezultacie - młodszemu pokoleniu trudno jest okazywać osobom starszym, oczekiwany społecznie, szacunek, skoro działania wobec przedmiotów przedstawiciela tej ostatniej grupy wiekowej traktowane sa jako nieuzasadnione ekonomicznie, nieefektywne, utrudniaja proces trzymania ręki na pulsie, uciążliwe. $\mathrm{Z}$ kolei osobom starszym trudno jest zaakceptować działania podejmowane przez młodych, poddane presji nadążania i trzymania ręki na pulsie, gdyż jawią się one schodzącemu ze społecznej sceny pokoleniu jako rozrzutność i marnotrawstwo, a więc jako czynności niemoralne czy wręcz grzeszne. Rotowanie systemów przedmiotów pociąga więc za sobą nieustanne zderzanie się ze sobą, bardzo często w obrębie jednego gospodarstwa domowego, nie tylko trudnych do pogodzenia ze sobą i skonfliktowanych działań, ale też uruchamiających te ostatnie i legitymizujacych systemów aksjonormatywnych. Interesującym i płodnym poznawczo przykładem rozwiązywania tego rodzaju

${ }^{22}$ R. F. Fiedler, Mediamorphosis. Understanding New Media, London 1997. 
sprzeczności jest zmiana sposobu zabezpieczania przez rodziców przyszłości swoich dzieci. Nie polega ona dziś na przekazywaniu im zgromadzonych przez ojców i matki przedmiotów (mebli, ubrań, pościeli, pojazdów, narzędzi), ale raczej pieniędzy, i to też nie $\mathrm{w}$ formie materialnej - raczej $\mathrm{w}$ postaci polis i ubezpieczeń, kart podarunkowych i funduszy zgromadzonych na kontach inwestycyjnych. Pieniądze, jako abstrakcyjny środek wymiany, nie sa powiązane, jak obiekty materialne, ze specyficznymi typami praktyk i zasad moralnych, a więc dadzą się wpisać w każdy system rzeczy. Sprawia to z kolei, iż relacje pomiędzy pokoleniami zostają oparte na abstrakcyjnych powiązaniach, które każda z generacji konkretyzuje w swoisty dla siebie sposób, nie zaś na transmitowaniu konkretnych wartości, wzorów działań, nastawienia wobec rzeczywistości, których mediami były konkretne obiekty materialne.

Po szóste w końcu, cyrkulowanie systemów przedmiotów ma też inny skutek, który na pierwszy rzut oka stanowi pomost pomiędzy różnymi pokoleniami, a tym samym kreuje solidarność międzygeneracyjną. Mowa tutaj o zasadzie repetycji, która rządzi rynkiem dóbr kulturowych, a więc o traktowaniu kultury jako ogromnego magazynu dóbr, stylów i tendencji, które można dowolnie zdekontekstualizować, przenieść w nowe miejsce i czas, powiązać $\mathrm{w}$ nowe, nieistniejące dotąd całości - zremiksować, dokonać ich postprodukcji ${ }^{23}$. Remiks (który w tym wypadku przybiera postać profesjonalnego projektowania, stylizacji, produkcji dóbr, ale też autokreowania się konsumenta ${ }^{24}$ ) wiąże ze sobą zaczerpnięte $\mathrm{z}$ różnych systemów przedmioty w zupełnie nowe całości - a więc dokonuje wobec nich podwójnego ruchu: dekontekstualizuje obiekty materialne, pozbawiając je tym samym pierwotnych znaczeń, rekontekstualizuje, lokując je w obrębie zupełnie nowych całości. Efektem dekontekstualizacji jest zazwyczaj zrównanie statusu dóbr materialnych, sprowadzenie ich do roli tworzywa, elementu konstrukcyjnego, pozbawienie związków z czasem i miejscem wytworzenia, a więc też wypłukanie ich ze znaczeń, a tym samym otwarcie na nowe sensy i sposoby wykorzystania. Proces ten jest istotny $\mathrm{w}$ odniesieniu do sprzeczności generowanych przez rotowanie systemów przedmiotów, ponieważ podkreśla, iż to, co było, ma prawo istnieć dziś tylko na warunkach określonych przez współczesne zasady porządkujące panoplie rzeczy - a więc jako pusty znak oczekujący na wypełnienie go treścią i sensem, jako obiekt konotujący czas, w którym rzecz powstała, ale tylko poprzez bardzo stereotypowe obrazy i skojarzenia: klisze wizualne i znaczeniowe. Mówiąc jeszcze inaczej - fascynacja ,,szafiarek” garderobami ich matek i babć nie wynika $\mathrm{z}$ więzi łączącej je z bliskimi im kobietami, z traktowania rzeczy tam zgromadzonych jako przedmiotów dokumentujących to, czego już nie ma, czy jako obiektów ewokujących wspomnienia albo reprodukujacych emocjonalne relacje. Traktuja one te garderoby raczej jako magazyn niepowtarzalnych ubrań, które można uczynić elementami trudnych do skopiowania, powtórzenia, a więc też silnie ujednostkowiających stylizacji. Na podobnej zasadzie dla miłośnika youngtimerów, Fiat 125 z lat 70., pierwotnie należący do

\footnotetext{
${ }^{23} \mathrm{Na}$ ten temat zob. N. Bourriard, Postproduction. Culture as Screenplay: How Art Reprograms the World, New York 2005.

${ }^{24}$ Tak jak ma to miejsce w wypadku różnych strategii DIY, szafiarek, cosplayerów.
} 
rodziców, nie jest traktowany jako cenna, rodzinna pamiątka, zdolna przywołać wspomnienia czy podtrzymywać relacje z bliskimi, ale raczej jako obiekt, który poprzez swoją rzadkość staje się cenny, a opieka nad nim, jego rekonstruowanie, staje się ujednostkowiająca, przez swoją ekscentryczność, pasją. Miłośników youngtimerów fascynują pojazdy, których używanie dla pokolenia ich rodziców było najpierw pozytywnie waloryzującym, a potem stygmatyzującym funkcjoznakiem. Ratowanie tego rodzaju aut przed „umieraniem”, nie jest więc z pewnością forma, w jakiej wyraża się międzygeneracyjna solidarność, ale raczej subwersywnym gestem, który w ironicznej, kampowej formie przypomina pokoleniu rodziców, o tym, o czym chcieliby zapomnieć - o siermiężności funkcjoznaków, którymi się dawniej posługiwali, by się wyróżnić.

Kulturowy recykling i praktyki remiksowania obiektywizują międzypokoleniowe sprzeczności: ich istota jest przypisywanie dziś obiektom materialnym zupełnie odmiennego statusu niż ten, który posiadały one wcześniej. Dawniej ich sens wynikał z ulokowania w specyficznym, ściśle określonym kontekście, dziś jest on skrajnie sytuacyjny, przydatność przedmiotów zaś mierzona jest nie tyle ich użytecznością czy precyzyjnością $\mathrm{w}$ roli medium przekazywania znaczeń, ile raczej stopniem podatności na wypełnienie ich dowolnymi sensami, zależnymi od aktualnych potrzeb użytkownika lub konsumenta.

\section{ZAKOŃCZENIE}

Uwzględnienie obiektów materialnych jako istotnego aspektu relacji międzygeneracyjnych pozwala dostrzec, że te ostatnie opieraja się w dużej mierze na tym, co nieudyskursywione, nieurefleksyjnione, na „milczącej wiedzy" wpisanej w codzienne praktyki i nasze nawyki. Uwzględnienie przedmiotów jako istotnego aktora $\mathrm{w}$ procesach kształtowania się relacji międzypokoleniowych pozwala dostrzec złożony charakter tych ostatnich. Nie rozgrywaja się one nigdy pomiędzy abstrakcyjnymi, bezcielesnymi aktorami społecznymi, których różni wiek i poglądy, sposób postrzegania rzeczywistości, ani też pomiędzy pokoleniami, rozumianymi jako odrębne kategorie wiekowe. Uwzględnienie przy rozpatrywaniu interesujących nas tu relacji przedmiotów konkretyzuje tego rodzaju związki: zachodzą one zawsze pomiędzy osobami wyposażonymi w ciała, nawyki i przyzwyczajenia, specyficzne umiejętności posługiwania się narzędziami; są zawsze gdzieś ulokowane i możliwe dzięki temu, że pośredniczą w nich różnorodne materialne ekstensje i instrumenty; towarzyszą im emocje; są one współkształtowane przez lokalny i globalny kontekst gospodarczy i polityczny, przez stereotypy i uprzedzenia; maja swoją biografię i są zależne od szlaku, który dany związek przebył, i tak dalej.

Kiedy dostrzeżemy, iż jesteśmy ludźmi, przedstawicielami określonej kultury i niepowtarzalnymi jednostkami również dzięki przedmiotom i za ich pośrednictwem, zauważmy też, że trudno jest przekształcać interesujące nas tu relacje międzypokoleniowe, zmieniając jednostkową świadomość, apelując do poczucia zobowiązania i odpowiedzialności, przypominając o koniecznej solidarności pomiędzy pokoleniami, o naszych wzajemnych zobowiązaniach wobec siebie. Działania tego rodzaju, których najpełniejszym wyrazem sa kampanie społeczne skierowane przeciwko ageizmowi, promujące 
solidarność i przypominające o zobowiązaniach rodziców wobec dzieci, sa nieskuteczne, ponieważ operują na innym poziomie, niż ten, na którym wchodzimy $\mathrm{w}$ relacje $\mathrm{z}$ rzeczami, a za ich pośrednictwem $\mathrm{z}$ jednostkami składającymi się na różne pokolenia. W rezultacie opisywane tu działania, będące próbą transformowania świadomości, reprodukują to, co wszyscy wiemy, a czego nie jesteśmy w stanie urealniać w codziennych działaniach, dlatego że podporządkowane są one sile nawyku i przyzwyczajenia wykształconych przez odrębne systemy przedmiotów - pokoleniowe habitusy. Być może więc skuteczniejszym sposobem rozwiązywania pokoleniowych dylematów, których źródłem jest rotowanie panoplii rzeczy, jest dążenie do ograniczenia prędkości społecznego zużywania się obiektów materialnych. Promowanie zasad samoograniczenia się konsumpcyjnego, spowalniania tempa życia, minimalizmu, odpowiedzialnych środowiskowo stylów życia, odrzucania korzystania z jednorazowych form kultury materialnej jest $\mathrm{z}$ pewnością jednym ze sposobów na eliminację opisanych wyżej ambiwalencji. Należy jednak pamiętać o tym, że bardzo łatwo przekształcić te rozwiązania w elementy stylu życia dla uprzywilejowanych, w trendy konsumpcyjne, a także o tym, że podważają one centralną zasadę efektywności kapitalistycznego systemu produkcji - zasadę nowości i wzbudzenia nowych pragnień. Wprowadzenie w życie tych rozwiązań w sposób systematyczny wymagałoby więc przebudowania systemu na bardzo podstawowym poziomie, a więc też byłoby ogromnie kosztowne i ekonomicznie, i społecznie. Niewątpliwie jednak działania nakierowane na przeobrażenie naszych relacji z rzeczami, chociaż na pierwszy rzut oka nie maja nic wspólnego z międzypokoleniowymi stosunkami, to wyznaczaja kierunek przeobrażeń, którym powinny podlegać zachodnie społeczeństwa, o ile uznamy, iż warunkiem ich trwania i reprodukcji jest budowanie takiej formy społecznego świata, który byłby światem wspólnym dla wszystkich generacji. Rozwiązania problemu międzygeneracyjnych sprzeczności nie powinniśmy szukać więc w nich samych, ale raczej w będącym ich źródłem szerszym kontekście społecznym, a więc też $\mathrm{w}$ naszych relacjach $\mathrm{z}$ materialnością stanowiąca integralny, konstytutywny aspekt środowiska, w którym działamy. Problem polega na tym, że - jak powie B. Latour: ,przedmioty traktujemy jak fakty” ${ }^{25}$, a z faktami się nie tylko nie dyskutuje, lecz także traktuje jako niepodważalny aspekt rzeczywistości wyznaczający ramy naszych działań. W naszych relacjach z rzeczami, które toruja nasze działania i wyznaczaja to, jak myślimy, traktujemy je jak dane, zapominając, iż są one społecznym tworem, który - jak wszystko, co stanowi produkt interakcji - można zmieniać. Dlatego też poszukujemy rozwiązań międzygeneracyjnych sprzeczności w tym, co wydaje się nam transformowalne: świadomości, postawach, regułach prawnych, a ignorujemy znaczenie tego, co wydaje się nam twardą, obiektywną ramą działań - a więc przedmioty, i to mimo że mają one identyczny status, jak to, co usiłujemy modelować.

dr hab. Marek Krajewski

Profesor Uniwersytetu im. Adama Mickiewicza w Poznaniu

${ }^{25}$ K. Abriszewski, Poznanie, zbiorowość, polityka. Analiza teorii aktora-sieci Bruno Latoura, Kraków 2008, s. 335. 


\section{GENERATIONS OF THINGS}

\section{Summary}

The first part of the paper is a proposition of a replacement of the category 'intergenerational solidarity' (which is a rather idealistic, wishful thinking and descriptive term, cumbersome and difficult to use in the changing and complex social environment) with a term 'intergenerational ambivalence' as the latter refers to the conflicting expectations, commitments, norms, standards and actions of individual generations and their ambivalence, which, even if they divide the generations, constitute at the same time the essence of the intergenerational relations. Intergenerational ambivalence on the other hand much more precisely than intergenerational solidarity describes the relations between representatives of different generations as it very accurately reflects the specificity of the relations between generations that appear in the postmodern world with its conflicting expectations, as well as because it emphasises that the specificity of each category of generation reflects the ability of its representatives to cope with the contradicting ideas in their relations with older generations, and with ambivalences that are characteristic of a given place and time. The other part of the paper is an attempt to characterise the manner in which ambivalences that permeate the intergenerational relations are articulated in everyday actions, in particular in those realised through material culture, as well as the manner in which the specifics of today's material culture increases those conflicts. 
